\title{
Deficit Financing in Contemporary Economies: Effects and Implications
}

\author{
Mahfuzul Haque ${ }^{(1)}$ \\ Professor of Finance, Scott College of Business \\ Indiana State University, USA
}

\begin{abstract}
Ann Pettifor's paper on deficit financing elucidates how Keynesian policies in times of economic slumps reduce public deficits. A public misconception is that during economic downturns, increasing government expenditure will worsen the deficit. Deficit financing aims to increase economic output via creating/salvaging jobs and increasing productivity. Thus, the temporary increase in spending creates a longterm increase in economic output, so the size of the deficit in relation to GDP ultimately decreases. However, effective targeting of government expenditure is critical if it is to benefit the economy. Evidence from the United States, Taiwan, and Bangladesh, shows how deficit financing used effectively, and not solely to gain political capital, is necessary to produce economic growth.
\end{abstract}

Keywords: Deficit, GDP, Government Spending, Financial Crisis and Tax Cuts.

JEL Classification: E12, E50, E52, E62, F65, H62

KAUJIE Classification: R73, R81, G3, Q52

(1) I take this opportunity to thank Abdul Azim Islahi, the Editor in Chief, for inviting me to join the discussion forum on the lead paper 'Deficit Financing' or 'Deficit-Reduction Financing?' Debates in Contemporary Economics: Origins, Confusions and Clarity written by Ann Pettifor. I also like to express thanks to my daughter, Ms. Zahin Ambeeren Haque, Graduate Student in Economics at New York University (NYU) for her help. 


\section{Introduction}

A government to spur economic growth in the country usually carries out deficit financing, but whether or not it actually influences growth has been hotly debated. Despite the vast discussion of this provoking topic in the economics literature, no conclusive outcome has been reached. In many Least Developed Countries (LDCs), government budget shortfalls covered by deficit financing has played a vital role in building capital. Budget deficits may happen for many reasons, but it typically signifies an attempt to accelerate the economy by lowering taxes or increasing government spending.

Different schools of thought exist in the literature on how to relate the fiscal deficit to economic growth. In Keynesian economics, government expenditure is one important component of Aggregate Demand (AD) in the economy. When AD falls short (during recessions), the government can increase expenditure, which in turn will increase $\mathrm{AD}$, and in turn, will stimulate the economy. This solution based on government stimulus packages worked well to increase output, employment, and income to bring the U.S. economy out of the Great Depression of 1929-1933 and out of the most recent Great Recession of 2007-2009. The same practice was followed by several other countries over the years to stimulate $\mathrm{AD}$ and the pace of economic growth (Hussain \& Haque, 2017).

Developing counties often have low savings and investment compared to more developed countries. Thus, these countries often do not have enough resources to invest in major developmental projects. Deficit financing plays an important role to fill the difference. Nevertheless, deficit financing may also happen from government inefficiency due to tax evasion or wasteful spending. When forming fiscal policy, it is thus essential to keep in mind the causes for deficit financing.

Islamic financing is one of the rapidly growing segments in the financial sector of the world today and is thus an important topic of study. Many Western big banks, including Citigroup, HSBC, and Deutsche Bank, as well as financial capitals like London, Tokyo, and Hong Kong, are all going into the Islamic banking business. Many studies address the relationship between Islamic finance and economic growth and the role of Islamic banks in mobilizing savings to stimulate economic growth (Benes \& Kumhof, 2012; Wolf, 2014). Boukhatem and Moussa (2018), attempt in their study to empirically test the impact that Islamic banking loans had on the economic growth of 13 countries in the MENA reg-ion during the 2000-2014 period. The authors found strong evidence to suggest that the financial system development stimulated economic growth in the selected MENA countries over the studied period. Moreover, net-oil-exporting MENA countries do not appear to benefit from large oilfueled deposits that are likely to increase the scale of loans. They suggest that governments should consider implementing proactive and favorable economic and institutional policies that align with Islamic finance.

The remainder of this paper is structured as follows. Section 2 reviews the lead paper of Ann Pettifor (2019) and discusses some of the topics mentioned in the paper with reference to the U.S. economy. Section 3 presents a view of economic development with historical evidence from Taiwan, a once very poor nation that quickly became one of the wealthiest countries in the world, and current evidence from Bangladesh, a Muslim-majority LDC. Finally, section 4 concludes the paper.

\section{Discussion on the Lead Paper}

Ann Pettifor's (2019) paper on deficit financing elucidates how Keynesian policies in times of economic slumps reduce public deficits. A common misconception is that during economic downturns, since output decreases, increasing government expenditure will worsen the deficit. However, these arguments ignore the effects deficit financing has on the economy. Deficit financing aims to increase economic output via creating/salvaging jobs and increasing productivity. Thus, the temporary increase in spending creates a long-term increase in economic output, so the size of the deficit in relation to GDP ultimately decreases.

The mechanism that drives the increase in GDP from Keynesian policies is the multiplier effect, in which the increased output from government expenditure is more than the government expenditure itself. For instance, the cost of improving highways and roads is less than the gains in a nation's GDP 
stemming from more jobs, less costly trade, etc. Several advocates of austerity measures argue that the multiplier effects are small and exaggerated, and point to evidence such as "roads to nowhere" regarding infrastructure investments. These arguments do, however, have some kernel of truth to them; roads built in locations where they will not be heavily used will generally not increase output as much as roads built connecting densely populated areas. Effective targeting of government expenditure is crucial for a nation to get the most "bang for its buck". Recent advances in the field of spatial economics have made it possible to identify which locations benefit the most from certain government expenditures. For instance, Allen and Arkolakis (2016), use commodity flow data to show which parts of the U.S. would benefit the most from improvements to the interstate highway system.

Although deficit financing is crucial in times of economic slumps, it is important to keep in mind the political slant that deficit financing entails, as deficit financing is often used by policymakers to generate political capital. In 2002, then Vice President Dick Cheney said, "Reagan proved deficits don't matter" (Leung, 2004, para 29). President Reagan took office in January of 1983 and the national debt of the U.S. as on $9 / 30 / 1982$ stood at $\$ 1142$ billion and the debt/GDP ratio at that time was around $34 \%$. On 9/30/1990, the national debt stood at $\$ 3233$ billion and the debt-to-GDP ratio rose to $54 \%$. Reagan, a Republican president, gave tax cuts to spur growth. For the Republican Party, the statement "deficits do not matter" only applies when they are the party in power, but when the power changes hands from the Republican to the Democratic Party, the tune changes. Republicans then hurl loud clarion calls, claiming that entitlements and other social benefits need to be trimmed to cope with the rising debt. The chart below (table 1) shows the ratio of debt-to-GDP in the United States from 1982 to 2021 (projected) (see, Amadeo, 2018). In a New York Times op-ed dated October 18, 2018, Paul Krugman, a Nobel Laureate in Economics, wrote when the Trump tax cut was on the verge of being enacted, I called it "the biggest tax scam in history", and made a prediction: deficits would soar, and when they did, Republicans would once again pretend to care about debt and demand cuts in Medicare, Medicaid and Social Security.

Sure enough, the deficit is soaring. And this week Mitch McConnell, the Senate majority leader, after declaring the surge in red ink "very disturbing", called for, you guessed it, cuts in "Medicare, Social Security and Medicaid". He also suggested that Republicans might repeal the Affordable Care Act - taking away health care from tens of millions - if they do well in the midterm elections.

Any political analyst who didn't see this coming should find a different profession. After all, "starve the beast" - cut taxes on the rich, then use the resulting deficits as an excuse to hack away at the safety net - has been G.O.P. strategy for decades. (Krugman, 2018, paras 1-3)

Deficit financing will only increase output if it is used effectively and not used to win political points, as it is often done.

The Republican Party, however, has had a habit of raising the deficit not when the country is in need, but when it is beneficial to their own political interests, rather than the public interest. The conservative (Republican) practice of cutting taxes while spending millions on wars has led to the largest debt in half a century, and to one of the worst recessions of recent time (the 2008 financial crisis). Even before being sworn in as the president of the USA in January of 2009, the then president-elect, Barack Obama, had to work out emergency rescue plans for the economy in November-December of 2008. Obama inherited an economy in January of 2009 that was on the verge of collapse and had to take drastic action. The Federal Reserve, led by Ben Bernanke, slashed the interest rate, and in May of 2011, the interest rate was around $1 / 8 \%$ for 3 month T-bills. The country was not even out of recession, but again, eyebrows were raised by Republicans as to why interest rates were being kept so low, despite the fact that the country was still coping with the financial crisis of 2008. 
Table (1) National Debt by Year Since 1982: Compared to Nominal GDP and Major Events

\begin{tabular}{|c|c|c|c|}
\hline $\begin{array}{c}\text { End of Fiscal } \\
\text { Year }\end{array}$ & Debt (as of 9/30, in billions) & $\begin{array}{l}\text { Debt/GD } \\
\text { P Ratio }\end{array}$ & Major Events by Presidential Term \\
\hline 1982 & $\$ 1,142$ & $34 \%$ & \multirow{4}{*}{ Reagan budgets from $1^{\text {st }}$ term. Recession. } \\
\hline 1983 & $\$ 1,377$ & $37 \%$ & \\
\hline 1984 & $\$ 1,572$ & $38 \%$ & \\
\hline 1985 & $\$ 1,823$ & $42 \%$ & \\
\hline 1986 & $\$ 2,125$ & $46 \%$ & \multirow{4}{*}{ Reagan lowered taxes. S\&L Crisis. } \\
\hline 1987 & $\$ 2,340$ & $48 \%$ & \\
\hline 1988 & $\$ 2,602$ & $49 \%$ & \\
\hline 1989 & $\$ 2,857$ & $50 \%$ & \\
\hline 1990 & $\$ 3,233$ & $54 \%$ & \multirow{4}{*}{$\begin{array}{l}\text { Bush } 41 \text { budgets. Desert Storm. Recession. Debt growth } \\
\text { slowed. }\end{array}$} \\
\hline 1991 & $\$ 3,665$ & $59 \%$ & \\
\hline 1992 & $\$ 4,065$ & $62 \%$ & \\
\hline 1993 & $\$ 4,411$ & $64 \%$ & \\
\hline 1994 & $\$ 4,693$ & $64 \%$ & \multirow{4}{*}{$\begin{array}{l}\text { Clinton budgets. } \\
\text { Budget Act reduced deficit spending. }\end{array}$} \\
\hline 1995 & $\$ 4,974$ & $65 \%$ & \\
\hline 1996 & $\$ 5,225$ & $64 \%$ & \\
\hline 1997 & $\$ 5,413$ & $62 \%$ & \\
\hline 1998 & $\$ 5,526$ & $61 \%$ & \multirow{4}{*}{$\begin{array}{l}\text { Last Clinton budgets. } 9 / 11 \text { attacks. Recession. Bush added } \\
\$ 22.9 \text { billion to FY01 budget for War on Terror. }\end{array}$} \\
\hline 1999 & $\$ 5,656$ & $58 \%$ & \\
\hline 2000 & $\$ 5,674$ & $55 \%$ & \\
\hline 2001 & $\$ 5,807$ & $55 \%$ & \\
\hline 2002 & $\$ 6,228$ & $57 \%$ & \multirow{4}{*}{$\begin{array}{l}\text { First George W. Bush budgets. War on Terror cost } \$ 409.2 \\
\text { billion. Bank bailout cost } \$ 350 \text { billion. Bush tax cuts. }\end{array}$} \\
\hline 2003 & $\$ 6,783$ & $59 \%$ & \\
\hline 2004 & $\$ 7,379$ & $60 \%$ & \\
\hline 2005 & $\$ 7,933$ & $60 \%$ & \\
\hline 2006 & $\$ 8,507$ & $61 \%$ & \multirow{4}{*}{$\begin{array}{l}\text { War cost } \$ 752.2 \text { billion. Katrina cost } \$ 24.7 \text { billion. ARRA } \\
\text { added } \$ 241.9 \text { billion to FY09 budget. }\end{array}$} \\
\hline 2007 & $\$ 9,008$ & $62 \%$ & \\
\hline 2008 & $\$ 10,025$ & $68 \%$ & \\
\hline 2009 & $\begin{array}{l}\$ 11,910(\$ 11,000 \text { on Mar } 16 \\
\text { and } \$ 12,000 \text { on Nov } 16)\end{array}$ & $83 \%$ & \\
\hline 2010 & $\begin{array}{l}\$ 13,562(\$ 13,000 \text { on Jun } 1 \\
\text { and } \$ 14,000 \text { on Dec } 31)\end{array}$ & $90 \%$ & \multirow{4}{*}{$\begin{array}{l}\text { Obama Stimulus Act cost } \$ 400 \text { billion. Payroll tax holiday } \\
\text { ended. War cost } \$ 512.6 \text { billion. Great Recession and tax } \\
\text { cuts reduced revenue. }\end{array}$} \\
\hline 2011 & $\$ 14,790(\$ 15,000$ on Nov 15$)$ & $95 \%$ & \\
\hline 2012 & $\$ 16,066(\$ 16,000$ on Aug 31) & $99 \%$ & \\
\hline 2013 & $\$ 16,738(\$ 17,000$ on Oct 17$)$ & $99 \%$ & \\
\hline 2014 & $\$ 17,824(\$ 18,000$ on Dec 15$)$ & $101 \%$ & \multirow{3}{*}{$\begin{array}{l}\text { War cost } \$ 309 \text { billion. QE ended. Strong dollar hurt } \\
\text { exports. }\end{array}$} \\
\hline 2015 & $\$ 18,151$ & $99 \%$ & \\
\hline 2016 & $\$ 19,573(\$ 19,000$ on $\operatorname{Jan} 29)$ & $104 \%$ & \\
\hline 2017 & $\$ 20,245(\$ 20,000$ on Sep 8) & $103 \%$ & Congress raised debt ceiling. \\
\hline 2018 & $\$ 21,66(\$ 21,000$ on Mar 15$)$ & $104 \%$ & \multirow{4}{*}{$\begin{array}{l}\text { Trump tax cuts and spending above sequestration. } \\
\text { Congress suspended the debt ceiling until } 2019 .\end{array}$} \\
\hline 2019 & $\$ 22,703$ (est.) & $108 \%$ & \\
\hline 2020 & $\$ 23,901$ (est.) & $108 \%$ & \\
\hline 2021 & $\$ 25,020$ (est.) & $108 \%$ & \\
\hline
\end{tabular}

Source: (Amadeo, 2018). 
Paul Krugman wrote on May 11, 2011 in the New York Times Magazine that:

The global financial crisis of 2008-9 had its roots in more than two decades of growing complacency in wealthy nations, a complacency whose main financial manifestation was ever-growing leverage. Bankers and households alike piled on levels of debt that would have been sustainable only if nothing ever went wrong. Inevitably, something did and a result was to force much of the advanced world into a harsh process of deleveraging, of slashing spending to pay down debts. ... Well, as I see it, the biggest danger for the United States isn't that there's another financial crisis lurking out there, ready to pounce. It is instead that we'll get confused by all the crisscrossing signals in the global economy and end up focusing on the problems we don't have while ignoring the problems we do. Not to put too fine a point on it: I'm worried that Ben Bernanke may end up being bullied into raising interest rates when he should do no such thing. There will eventually come a day when the Federal Reserve Board should tighten - but that day is years away. (Krugman, 2011, para 5 \& 13)

As Ann Pettifor (2019) writes "given these flaws, it is no wonder that the economics profession as represented by the London School of Economics could not answer the British Queen's question: Why was the crisis not foreseen? Why did no one notice it?" (p. 67). This was a question raised by the British Queen in November of 2008 after the worldwide financial crisis had erupted and has been cited many times as embodying the public's consternation. The financial crisis of 2008 happened under the watchful eyes of President G.W. Bush (or Bush II), a Republican president and his vice president, Dick Cheney, whose quote of 2002 "deficits don't matter," gave us the entire dreadful outcome. Paul Krugman addresses the concern raised by the British Monarch with the query "how did economists get it so wrong"? In a New York Times article dated September 02, 2009, he writes,

few economists saw our current crisis coming, but this predictive failure was the least of the field's problems. More important was the profession's blindness to the very possibility of catastrophic failures in a market economy. ... As I see it, the economics profession went astray because economists, as a group, mistook beauty, clad in impressive-looking mathematics, for truth. ... $[\mathrm{He}$ concludes] When it comes to the all-too-human problem of recessions and depressions, economists need to abandon the neat but wrong solution of assuming that everyone is rational and markets work perfectly. The vision that emerges as the profession rethinks its foundations may not be all that clear; it certainly won't be neat; but we can hope that it will have the virtue of being at least partly right. (Krugman, 2009, paras 3, 6 \& last para)

Taking into account the possibility of market failure is crucial for designing policy and the belief that deficit financing is unnecessary as "markets will fix themselves" is also naïve, as evidence shows that markets can break down.

\section{Economic Development}

In the context of developing countries, large government expenditure programs aimed at increasing output and decreasing poverty are known as "big push" strategies. The poverty trap literature has argued that without a big push, underdeveloped countries will find them stuck at a low GDP state and will be unable to move up. To many, this strategy of spending when lacking the means may seem foolish, but historical evidence shows that it pays off. Taiwan, for example, is considered one of the major "growth miracles" of the $20^{\text {th }}$ century (al-Fathi, 2012). Although many people argue that it was the high savings rate that caused this rapid economic growth, they are neglecting the fact that before Taiwan began saving a lot, the government made significant financial investments to restructure their agricultural sector, build schools, and construct roads. These investments paid off, by increasing agricultural output so that residents of Taiwan no longer had to spend the majority of their incomes on food, by allowing more residents to obtain formal education, and by facilitating migration/commuting to urban areas where incomes are higher. Thus, since Taiwanese residents had more disposable income, they were able to naturally save more. This increase in savings lowered the interest rate, thereby spurring on more private investment. Taiwan's initial expenditures in the 1950s, when it was a poor, underdeveloped country, allowed Taiwan to grow rapidly. All initial expenditures had large multiplier effects, which allowed Taiwan's GDP per capita to become one of the highest in the world. 
Bangladesh, the world's third largest Muslimmajority country, provides recent evidence on the importance of deficit financing for economic growth. Although the United Nations classifies Bangladesh as the largest least developed country (LDC) in terms of population and economic size, it is likely that Bangladesh will leave the LDC category by 2024 , propelled by better health and education, and an economic boom (Gay, 2017). According to the World Bank's report, "Bangladesh has an impressive track record for growth and development, aspiring to be a middle-income country by its $50^{\text {th }}$ birthday [2021]" (The World Bank, 2018b). GDP for the country was $\$ 249.724$ billion in 2017 . In the past decade, the economy has grown at nearly 6 percent per year (The World Bank, 2013; The World Bank, 2018a). The Bangladeshi government has unveiled a record Tk 4,64,573 crore (about 55.31 billion U.S. dollars) national budget for the 2018-2019 fiscal year starting in July 2018. The budget deficit is expected to be around $5 \%$ of GDP. About $11.7 \%$ of the budget-financing source will be from foreign loans and grants ("Muhith unveils Tk 4,64,573cr budget for FY19", 2018).

Hussain and Haque (2017) research the relationship between fiscal deficit and its impact on economic growth in Bangladesh. The authors highlight that the quality of government expenditure is important and that government expenditure should be undertaken after careful planning. It should be effectively implemented so that benefits of such projects are substantial. The government should give priority to projects that deal with public goods and generate positive externalities. The private sector alone will not provide enough of such goods, some of which are essential to national development. Nevertheless, the government must keep the deficit under control so that the growth of the economy may continue without any pause. Fiscal policy has an important role on the growth of the economy in Bangladesh. Therefore, it is imperative on the government's part to carefully formulate the tax policy (to generate revenue) and expenditure policy (checking wasteful expenditure and curbing corruption), keeping in mind that such policies have a significant impact on growth. Fiscal policy adjustment that reduces unproductive expenditure and protects expenditure in the social sector can lead to additional sustainable level and is likely to result in faster growth. The level of government expenditure should be set so as to avoid huge deficits leading to debt financing and the crowdingout effect of private investment. If deficits become unsustainable, it can lead to higher interest payments, loss of confidence, and lower GDP growth rate. Given the low level of savings and investable funds, as is typical in a developing country like Bangladesh, the need to mobilize more resources (both foreign and domestic) to invest in productive sectors of the economy can hardly be overemphasized. The authors end by saying that, in the economics literature, there is no definitive conclusion as to whether fiscal deficits help or hinder economic growth for a country, and many argue that a fiscal deficit leads to economic growth, which cannot be achieved only through domestic savings, as the current level of domestic savings may not be enough for investment. It can be accepted safely that a certain level of fiscal deficit is good for economic growth, if the borrowed money is spent for beneficial projects, and the return from such investments exceeds the funding cost.

\section{Conclusion}

Increasing spending when times are bad may seem counterintuitive. However, as Pettifor (2019) emphasizes, common wisdom regarding spending for private households is not applicable when discussing government expenditure. A government's purpose is to serve its citizens, especially in times of need, and thus it is the responsibility of a government to finance job creation schemes and other programs to increase output when the economy is in a slump. Nevertheless, this review of Pettifor's article emphasizes the need to target deficit financing appropriately, in both developed and developing countries. Deficit financing should not be used to win political points or enable corruption, but should be targeted to provide for the segments and aspects of society, which are most in need of and will make the most out of an economic boost. By effectively targeting its expenditures to make the most of the multiplier effect, the size of the economic "cake", as Pettifor puts it, will grow and thus the budget deficit's share of the "cake" will ultimately decrease. 


\section{References}

Allen, T., \& Arkolakis, C. (2016). The Welfare Effects of Transportation Infrastructure Improvements (NBER Working Paper). Retrieved from:http: //papers.nber.org /conf_papers/ f103659/f103659.pdf

Amadeo, K. (2018, November 28). National Debt by Year Compared to GDP and Major Events: U.S. Debt by Year Since 1929. Retrieved from: https://www.the balance.com/national-debt-by-year-compared-to-gdpand-major-events-3306287

Benes, J., \& Kumhof, M. (2012). The Chicago Plan Revisited (IMF Working Paper No. WP/12/202). Retrieved from: https://www.imf.org/ /media/Web sites/IMF/imported-full-text-pdf/external/pubs/ft/wp/ 2012/_wp12202.ashx

Boukhatem, J., \& Moussa, F.B. (2018). The effect of Islamic banks on GDP growth: Some evidence from selected MENA countries. Borsa Istanbul Review, 18(3), 231-247.

al-Fathi, S. (2012, September 9). Taiwan Miracle is a good example economic progress for others: Despite a initial lack of resources, the country has sustained economic growth. Gulf News. Retrieved from: https:// gulfnews.com/business/analysis/taiwan-miracle-is-agood-example-economic-progress-for-others1.1071868

Gay, D. (2017, October 30). Booming Bangladesh looks forward to LDC graduation. Retrieved from: https:// www.un.org/ldcportal/booming-bangladesh-looksforward-to-ldc-graduation/

Hussain, M.E., \& Haque, M. (2017). Fiscal Deficit and its Impact on Economic Growth: Evidence from Bangladesh. Economies 2017, 5(4), 37. Retrieved from: https://res.mdpi.com/economies/economies-0500037/article deploy/economies-0500037.pdf? filename $=\&$ attachment $=1$

Krugman, P. (2009, September 2). How Did Economists Get It So Wrong? The New York Times Magazine. Retrieved from: https://www.nytimes.com/2009/09/ 06/magazine/06Economic-t.html
Krugman, P. (2011, May 11). Inflation and Economic Hooliganism. The New York Times Magazine. Retrieved from: https://www.nytimes.com/2011/05/ 15/magazine/paul-krugman-how-the-financial-crisiswas-wasted.html

Krugman, P. (2018, October 18). The Trump Tax Scam, Phase II: Deficits are up? Cut Medicare and Social Security! The New York Times. Retrieved from: https:// www.nytimes.com/2018/10/18/opinion/taxesmedicare-social-security-midterms.html

Leung, R. (2004, January 9). Bush Sought 'Way' To Invade Iraq? CBS News, '60 Minutes'. Retrieved from: https://www.cbsnews.com/news/bush-sought-way-toinvade-iraq/

Muhith unveils Tk 4,64,573cr budget for FY19 setting 7.8pc growth target. (2018, June 7). Retrieved from: https://www.thedailystar.net/bangladesh-nationalbudget-2018-19/muhith-placing-taka-468000-croremega-national-budget-for-2018-19-fiscal-year-1587 760

Pettifor, A. (2019). 'Deficit Financing' or 'DeficitReduction Financing?' Debates in Contemporary Economics: Origins, Confusions and Clarity. Journal of King Abdulaziz University: Islamic Economics, 32(1), 67-78.

The World Bank. (2013, April 15). Bangladesh: Bolstering Economic Growth to Reduce Poverty. Retrieved from: http://www.worldbank.org/en/results/2013/04/15 /bangladesh-bolstering-economic-growth-to-reducepoverty

The World Bank. (2018a). Data Bank, World Development Indicators. Retrieved from: https://databank.worldba nk.org/data/reports.asp $x$ ?soure $=2 \&$ type $=$ metadata\&seri es $=$ NY.GDP.MKTP.CD\#

The World Bank. (2018b, October 8). The World Bank In Bangladesh. Retrieved from: https://www.worldbank. org/en/country/bangladesh/overview

Wolf, M. (2014). The shifts and the shocks: What we've learned - and have still to learn - from the financial crisis. London, UK: Penguin Press. 
Mahfuzul Haque is currently Professor of Finance at the Scott College of Business (SCOB), Indiana State University, USA. He obtained his Ph.D. and M.A. from University of New Orleans, MBA's from Indiana University and Dhaka University. His undergraduate degree was in Electrical Engineering from the Bangladesh University of Engineering and Technology (BUET), Dhaka. He has published in several international journals including, Pacific Basin Finance Journal, Quarterly Review of Economics and Finance, Quarterly Journal of Business and Economics, Multinational Business Review, Journal of Social, Political and Economic Studies, Review of Middle East Economics and Finance, Journal of Risk Finance, Journal of Emerging Market Finance, International Review of Applied Financial Issues and Economics, International Journal of Financial Studies, Journal of Academy of Finance, International Journal of Business and Emerging Markets, Journal of Economics and Political Economy, International Journal of Financial Studies, Economies, Journal of Chinese Economic and Business Studies, and Journal of Advances in Economics and Finance. He has presented several research papers at conferences and has received the Top Conference Paper Award in International Finance in 2001. He also received the Outstanding Researcher Award from the Scott College of Business in 2011, 2018, and the McGraw Hill Distinguished Paper Award in 2015. He also serves as reviewer for journals and has received the Emerald Literati Award in 2018 for being an outstanding reviewer. He worked for several years in the public and private sectors holding managerial positions with British MNC's.

E-mail: Mahfuzul.Haque@indstate.edu 


\section{تمويل العجزفي الاقتصيادات المعاصرة: الآثاروالنتائج}

أستاذ التمويل، كلية سكوت للأعمال، جامعة ولاية إنديانا، الولايات المتحداة الأمريكية

المستخلص. توضح ورقة آن بتيفور حول تمويل العجز كيف أن السياسات الكينزية في أوقات الركود الاقتصادي تقلل من العجز العام. هناك اعتقاد عام خاطئ أن زيادة الإنفاق الحكومي خلال فترات الانكماش الاقتصادي ستؤدي إلى تفاقم العجز. يهدف تمويل العجز إلى زيادة الإنتاج الاقتصادي من

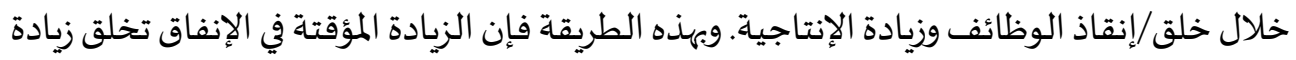

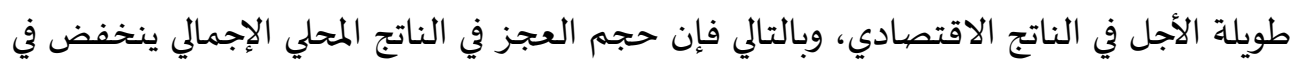
هاية المطاف. ولكن لكي تؤدي هذه النفقات الحكومية وظيفتها وتكون مفيدة للاقتصاد، فإن فئن

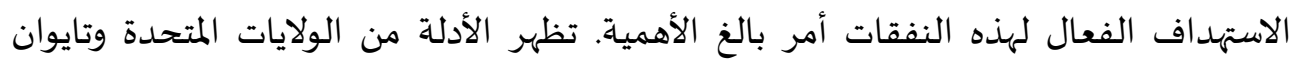

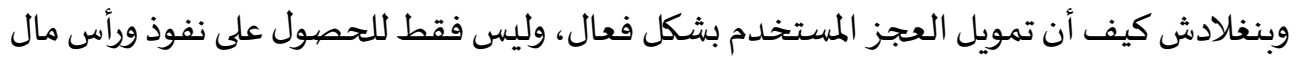
سياسي، ضروري لتحقيق النمو الاقتصادي. الكلمات الدّالة: العجز، الناتج المحلي الإجمالي، الإنفاق الحكومي، الأزمة المالية وتخفيض الضرائب. تصنيف E12, E50, E52, E62, F65, H62 :JEL تصنيف R73, R81, G3, Q52 :KAUJIE 